\title{
Work Motivation, Competence, and Compensation are Affected on Employee Performance
}

\author{
Sugiharti ${ }^{1}$, Kiswoyo $^{2}$ \\ Sekolah Tinggi Ilmu Ekomomi Totalwin, Semarang ${ }^{1,2}$ \\ \{sugiharti@stietotalwin.ac.id ${ }^{1}$, kiswoyo@stietotalwin.ac.id² ${ }^{2}$,
}

\begin{abstract}
The purpose of this study was to determine and analyze influence of Work Motivation, Competence, and Compensation to give effect on employee performance. This research was conducted to determine the institutional change with a decrease in employee performance. This study was conducted using a survey of 74 employees working at BAP Mandiri DAPM in Boja District, Kendal, Central Java. Analysis was carried out using multiple linear regression analysis.Based on test results show that Work Motivation and compensation have a positive effect on employee performance. while competence does not affect employee performance. So that DAPM Bina Mandiri must always motivate and improve employee competence to improve employee performance.
\end{abstract}

Keyword: Motivation, Competence, Compensatio, employee performance

\section{Introduction}

\subsection{Background}

People are always play an active role in every organization because people become planners, actors and decision maker of the realization in organizational goals. The goal of organization will not be realized without the active role of employees even though it is supported by the infrastructure owned by the organization that sounds sophisticated. The focus of MSDM study is on the problem of labor that is regulated in the order of functions in order to be effective and efficient in realizing the objectives (Ariyanti, 2014). The purpose of a company or organization in emphasizing the importance of the quality of human resources is as a standardization or indicator. Well, that human resources or labor obtained can actually work in accordance with what the company wants. The goal of most employees in a work is not only limited to physical and biological needs, but also has psychological and social needs, and all employees' needs, it will be able to push the spirit of employee work (García, 2005; Youndt, et al., 1996).

Employees, always play a role in every organization actively. Moreover, employees also as planners, actors and at the same time as the decision maker in realization of the organization's goal. The organization's objective will not be realized without a role of employees. No matter how good the support and infrastructure is, or the available of organization, when that thing is not balance enough with the support system such as competencies and abilities of employees, then the objectives of the organization will not be achieved. The focus of study is the problem 
of labor that is regulated in the order of its functions in order to be effective and efficient in realizing the objectives of the organization. There are essentials things in organization's demand such as acquire, develop, and maintain about quality of human resources. However, the availability of competent and highly capable human resources is an urgent need in every sector of organization based on the environments and technologies. Both things above are required in every organizations sector in order to have competent and highly capable employees.MSDM's strategy also concerns on competency issues in technical, conceptual and human relationships (Sung \& Choi, 2016).

Management of labor competencies includes several competencies such as: input-based competencies, transformational competencies, output competencies. The influence of competence on performance can be seen from the level of competence that has practical implications in human resource planning. Then, it can be seen from the picture that the competencies of knowledge and expertise are tended to be real and relatively, also more visible on the surface as one of the characteristics that employees have (Zhang, et al., 2010; Wahyudi, 2014). In addition, BKAD (Badan Kerjasama Antar Desa) is an institution service of independent empowerment and trust fund has its goal to encourage the improvement of quality and participatory development at the sub-district level and preservation also in development of PNPM Mandiri on rural activities. In 2015, PNPM Mandiri Rural was entering the end of the program. The success of PNPM Mandiri can be observed by the ratification of Law No. 6 of 2014 on Rural area, which began from the management of community participation was the result of the PNPM Mandiri Rural program.

The end of PNPM Mandiri Rural program does not mean that it loss of assets produced by PNPM Mandiri Rural. However, the results of the PNPM Mandiri Rural program is adopted by the mandate of Law No. 6 of 2014. BKAD, as an institution formed by the Independent Empowerment and Trust Fund which has scope at the sub-district level must be able to fit with the ratification of the Village Law. In other hand, BKAD should be able to synergize between PNPM policy post-program that changed into Independent Empowerment and Trust Fund with Village Law. In relation to BKAD Institutions and BKAD form institutions, the function of BKAD is to formulate, discuss, and establish to the strategic plans on development of the Community Empowerment Trust Fund in the field of micro finance. Moreover, the organization is to expand widely with all activities that carried out to achieve the desired goals by using available human resources. Hence, in achieving these goals, it is not enough to obtain employees who are considered the most competent, but not less important by continuously providing motivation and compensation to employees to be more passionate in carrying out their duties in the organization (Zigarmi and Peyton , 2018).

The motivation of work has an important role in growing passion, happy feeling, and eager to work optimally. Employees who have strong in work motivation will have a lot of energy to do such activities in contrast to the employee who have high intelligence can fail due to lack of motivation. Another results will be optimal if there is the right motivation. Low-working motivation in employees is a syndrome of unfavorable because the low of work-motivation on them shows an indifferent attitude towards social life, including towards the future of their nation. Also on economic success of a nation is determined by the high motivation of its citizens. In other words, the development of nation will be successful based on the motives of high-achieving created by the citizens. In the learning process, there are certainly failures and successes. The failure of employees in carrying out their duties does not entirely come from the employee but also by the organization that is not successful in providing motivation and able to raise the spirit of employees in working (Zhang, et al., 2010; Zigarmi \& Peyton, 2018). 
The success of employees' can not be separated from the motivation of the employee itself. Therefore, basically work motivation is a main factor that determines the success of employees in carrying out it tasks that the organization charged to them. Employees will also be more motivated if they get satisfactory compensation from the organization as a sign of appreciation for their work. In addition, such of organizations certainly can not be separated from employees, with rapid development of technology, sometimes they know more quickly about life forms that far away out there. The dependency of each other makes us need to appreciate the work of others. Appreciation in the world of education is important and must be done to give a new nuance that is eagered to seek achievements for the future of the organization under DAPM Bina Mandiri, Boja district. DAPM Bina Mandiri which located in Boja district is a Amanah Fund Management Group organizing as an empowerment-based economic business with a Women's Savings and Loan business unit with revolving funds, cooperatives, Procurement of Goods and The Crossing of payment services on line.

\subsection{Problem Identification}

The end of PNPM Mandiri Rural program does not mean that it loss of assets produced by PNPM Mandiri Rural. However, the results of the PNPM Mandiri Rural program is adopted by the mandate of Law No. 6 of 2014. BKAD, as an institution formed by the Independent Empowerment and Trust Fund which has scope at the sub-district level must be able to fit with the ratification of the Village Law. BKAD should be able to synergize between PNPM policy post-program that changed into Amanah Pemberdyaan Masyaakat Fund with Village Law. In relation to BKAD Institutions and BKAD form institution, the function of BKAD is to formulate, discuss, and establish on strategic plans as development of the Community Empowerment Trust Fund in the field of micro finance. In order to expand widely with all activities of company, it carried out to achieve the desired goals by using available human resources, but to achieve these goals, it is not enough to obtain employees who are considered as the most competent, but not less important by continuously providing motivation and compensation to employees to be more passionate in carrying out their duties in the organization (Zigarmi and Peyton, 2018).

\subsection{Research Problem}

Human resource is an essential element for the organization that businesses can run well. In the absence of human resources quality, the organization will be difficult to run and operate properly. Quality resource can affects the performance of employee. In this study there are factors that tested on employee performance. The elements that contains on that as the formulation of problems in this study such as What work-motivation is, competence, and compensation to influence the employee performance.

\section{Theoretical Background}

\subsection{Work-Motivation}

Human being as one of the basic components in a public organization that must have a motivation stored in the heart or desire that can spur to achieve the things that desired. Motivation is a concept that describes about the strengths and be existed in the employee who 
initiates and can direct through their behavior of person. Hence, the work motivation is an encouragement, effort, and desire that exists in human being also gives power and directs behavior in the implementation of environment task. The essence of work motivation is the urge to do everything better than others in doing activities to achieve goals. Motivation is the desire within a person that causes the person to take action. However, it is a series of attitudes and values that influence the individual to achieve specific results according to the individual's goals.

Motivation is the willingness to make high-level efforts in order to achieve organizational goals conditioned by the ability of the business to satisfy the needs of individuals. Motivation also as a mobility giver that creates the excitement of one's work, so that they want to work together, work effectively, and integrate with all efforts to achieve satisfaction. Motivation is a factor that encourages people to act in certain way. Start to the point of rejecting in a meaning of motivation, work motivation is something that gives rise to encouragement or spirit of work. In other words, work motivation is the driver of work spirit. Based on the explanation above, it can be concluded that work motivation is an activity that dropped in the channeling, maintaining, and encouraging the behavior of a person to perform in certain action or action optimally to achieve the goals of organization itself.

The purpose of a company or organization in emphasizing the importance of the quality of human resources is a standardization or indicator. Well, that human resources or labor obtained can actually work in accordance with what the company wants. The purpose of a large number of employees in work is not only limited to physical and biological needs, but also has psychological and social, and all employee needs, also it will be able to spur the spirit of their work. Human beings will be encouraged to meet the most powerful needs according to the time, circumstances, and experiences which concerned in following a hierarchy. Maslow's theory in the hierarchy of needs can be seen in the image below.

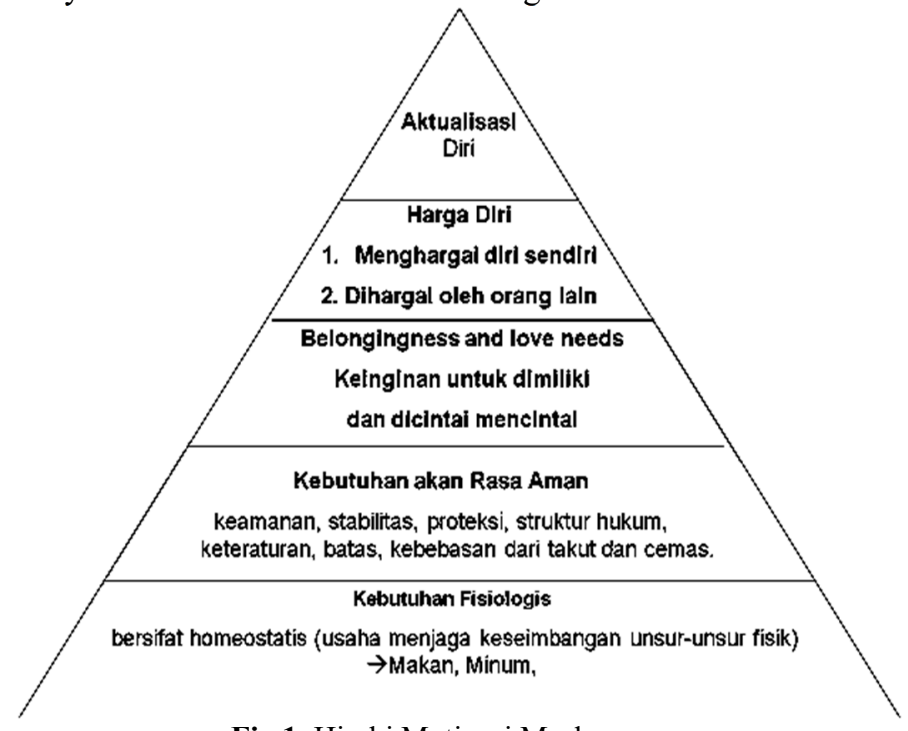

Fig 1. Hiarki Motivasi Maslow

In this hierarchy of needs there are five levels, namely: 
a. The need to maintain life (physiological): This main need is what encourages each individual to do any work, because he will get a reward, either in the form of money or goods to be used to meet this main need. For example: food, beverages, rest/sleep, sex.

b. The need of secure: After the first and main needs are met, there is a feeling of the need to meet the needs of security / protection. The need for physical and spiritual salvation, personal security, security and fear-free. Each individual wish for secure things on their life, including their family.

c. Social needs: Every human being always feels a thing to associate with other human beings. As long as people's lives in this world can not be separated from the help the others.

d. The need for appreciation: The need for recognition as the status and achievements to be achieved. People are trying to do work that allows for respect / community respect.

e. The need for self-actualization: The need for self-achievement and self-realization. This is the need for the highest peak, so that one wants to maintain for achievements optimally.

Maslow's theory assumes that people seek to satisfy fundamental needs (physiological needs) before directing their behavior to higher needs. Some of Maslow's insight as follows:

1. Satisfied needs will stop motivating.

2. Insatiable needs can lead to frustration, conflict, and stress.

3. Maslow assumes that people have a need to grow and develop, and as a result, will continue to strive to move up in the hierarchy to meet satisfaction.

4. Higher needs will not be active or triggered until the dominating needs can be met. One can only rise in the hierarchy of needs when the need at a low level is already being addressed.

In an organization activity, including working life in a business organization, the aspect of absolute work motivation gets serious attention from managers. Here are the four main considerations below:

a. The philosophy of human life revolves around the principle of "quit pro quo", which in layman's language is reflected by the saying that "there is yams there is taro, there is a favor there is reciproge".

b. The dynamics of human needs are very complex and not only material, but psychological.

c. There is no saturation point in the fulfillment of human needs.

d. Individual differences in organization or company result in the absence of any motivational techniques that are equally effective for everyone in the organization as well as for a person at different times and conditions.

There are six technique of motivation theory such as:

1. Management based on goal or Management by objective (MBO); most recently it is very popularly used by management in providing positive motivation for its subordinates.

2. Employee award program; the program can take various forms such as promotion, promotion, raise, award charter, and so on.

3. Employee order program; a participatory process to utilize all employee capabilities and intended to encourage increased commitment to the success of the organization. For this technique to be truly effective, management needs to pay attention: (1) The availability of enough time for employees to participate; (2) The availability of issues involving employees must be relevant to the interests of Employees; (3) Employees must have intellectual ability, technical ability, and communication ability in order to be able to contribute substantially; (4) Employee engagement is supported by organizational 
culture; involvement in the form of employee representatives can take the form of participation through representatives appointed as representatives of employees, employee boards, and board members of the board of directors.

4. Various of Rewards programs; in a various ways organizations use to supplement employee earnings, depending on individual and organizational performance including rewards based on the products produced, profit sharing plans, and more value sharing.

5. Skill-based on reward plan; intended to encourage employees to become high achievers, as well as a tool to encourage employees to always add skills by following the flow of technology faced by organizations today, such as new strategies and new environmental conditions.

6. Flexible benefits; in the form of assistance and organizational services that although not directly increase the salary earned each month, but can be received and utilized to ease the financial burden of employees.

The application of theories and techniques clearly shows that the formula says that in order to be effective in changing behavior and worked-improving. Here, the managers must put forward motivational theories and techniques to the goals, expectations, ideals, desires, and needs of subordinates individually. In short, there is not to use a generalization approach, as if a motivational technique is used equally for everyone in the organization or for someone's conditions. There are several behavior that can motivate employees: (1) How to interact; (2) Become an active listener; (3) Drafting challenging goals; (4) Problem solving approaches and behavioral-focused goals instead of personal; (5) Information that uses reinforcement techniques.

\subsection{Competency}

The concept of competency begins to become a trend and much talked about and now this thing is very popular, especially in the "modern" environment of multinational and national companies. The terminology and concept of competency has actually been introduced by an American management writer in the book entitled The Competence Manager. In that book, Boyatzis presented the evidence that United States business managers must have certain competencies in the business and economy of the United States does not want to be defeated by Japan and Europe. Here are the terminology of competency such as:

a. Competency comes from English competency which means: (1) proficiency, ability, competence; (2) authority.

b. Competence is an ability to carry out a job or task based on skills and knowledge and supported by the attitude of work required by the work. Furthermore it is said that the concept of self is one's attitude, values or self-image. Confidence is a person's belief that they can be effective in almost every situation is part of people's self-concept. Knowledge is information that people have in a specific field. Knowledge is a complex competence. Skills are the ability to perform certain physical or mental tasks. Mental competence or cognitive skills include analytical and conceptual thinking.

c. Competence as a characteristic of a person that can be shown, which includes knowledge, skills, and behavior, which can produce performance and achievement. Competence, expertise, and measurable knowledge are at the core of the performance management process across all companies.

d. An underlying characteristic of an individual that is casually related to creterion referenced effective and/or superior performance in a job or situation"or competence is a 
basic characteristic of a person (individual) that affects the way of thinking and acting, making generalizations to all situations faced and lasting long enough in human beings.

e. Job-oriented competencies are abilities, behaviors or skills that have been shown to give rise to or predict superior performance in a particular job.

f. Law No. 13 of 2003 on Ketenagakerjaan, mentions competence is the working ability of each individual that includes aspects of knowledge, skills, and work attitudes in accordance with standarization.

g. Several definitions of competence:

1. Quoting from the K.U. Leuven Association defines that the understanding of kompetence is the integration of knowledge, skills, and attitudes that make it possible to implement one effective way.

2. The Decree of the Head of the State Personnel Agency No. 46A of 2003 dated November 21, 2003 is determined that "Competence is the ability and characteristics possessed by a Civil Servant in the form of knowledge, skills, and attitudes of behavior required in the implementation of his/her duties, so that the Civil Servant can carry out his duties professionally, effectively, and efficiently".

3. Competency is a combination of skill, knowledge, and behavior that can be observed and applied critically for the success of an organization and work achievement and employees' personal contributions to their organization. Departing from some of the above understandings, it can be concluded that competence is something inherent in a person that can be used to predict his level of performance. Something in question can concern motives, concepts of self, nature, knowledge and abilities / expertise.

\subsection{Several Factor Influenced the Competency}

Organizations are growing rapidly following rapid and global change. As often as possible with the dynamics of these changes the assessment needs to be done continuously. Leaders must have the competencies necessary to be creatively able to solve various problems and challenges due to rapid and uncertainty. The factors that influence competence are:

a. Beliefs and Values. People's beliefs about him or others will greatly influence behavior.

b. Skills play a role in most competencies. The development of skills specifically related to competencies can have an impact on both the organization and individual competencies.

c. Experience. The expertise of many competencies requires the experience of organizing people, communication before the group, solving problems, and so on.

d. Personal Characteristic Personality can affects on manager's skills, and employee in ever competency including in problem solving, showing care, interpersonal, the team work, and giving an influence in making relation.

e. Motivation is a factor that lives in competency that changeable. It can be changed through giving support, and appreciation to the lower level of employee. Then, giving the acknowledgment and personal caring from the leader can bring positive impact to the employe's motivation. In case, there is a manager can push for someone's motivation and then it can be related to the goals of work, they will find the way to achieve the goals of its business things. In addition, they also will find an increasing way in achieving amount of competency of them.

f. Emotional Issue, the obstacle of Emotional can be bordered in mastering competency. 
g. Intellectual Ability, Competency is based on the cognitive perspective just like conceptual perspective also analytic. Those perspective above will go to the next level by the experience of worker.

h. Organization Culture, is influenced to the competency of human resource in every activity.

From the components above, can be grouped factors that affect performance is knowledge that is intellectual ability, skills, and attitudes that include beliefs, personal character, motivation, and emotional issues. Components or elements that create the competency include:

1. Personal character (traits), is a physical characteristic and a consistent reaction or response to a situation or information.

2. Self concept. The concept of self is a device of attitude, value system or self-image that a person has.

3. Knowledge, is the information a person has about a specific area.

4. Skills, are the ability to perform a certain set of physical or mental tasks.

5. Motivation (motives), Motive is something that a person consistently thinks or wants, which will then direct, guide, and select a particular behavior against a number of actions or objectives.

Based on the components above can be grouped into attitudes that include personal character, self-concept, motivation; knowledge; and skills. From the description above can be determined the right competency understanding. Then, for this research is a basic characteristic of a person who influences the way of thinking and acting, based on knowledge, skills, and attitudes, which results in the ability to carry out a job or task so as to produce high performance.

\subsection{Compensation}

Basically, people working in any corporate in order to earn money and make their life more better than before. For this reason, an employee begins to appreciate hard work and increasingly shows loyalty to the company and that is why the company rewards employees' work achievements by providing compensation. One of the ways management improves work performance, motivates and improves employees' performance is through compensation. Compensation is important for employees as individuals because the amount of compensation reflects the size of their work among the employees themselves, their families and communities. Compensation is also called an award and can be defined as any form of award given to employees in return for the contributions they make to the organization.In addition, there are several definitions of compensation from several figures, namely:

a. Compensation is what a worker received as a salary of the work he or she provides. Starts from hourly wages and periodic salaries are designed and managed by the personnel section.

b. Compensation is anything that is unconstitutional or considered to be retaliation or equivalent. The definition of compensation is also contained in various literatures presented by some experts, among others: (1) Compensation is a broad term relating to financial rewards received by people through their staffing relationships with organizations; (2) Employee compensation is any form of payment or reward given to the employee and arising from the employee's employment. (3) Compensation is everything that employees receive in return for their work. Well, through compensation 
employees can improve work achievement, motivation, satisfaction, performance as well as can improve their life.

Compensation is all the compensation an employee receives from his company as a result of the services or personnel he has provided to the company. Compensation is calculated based on the evaluation of work, the calculation of compensation based on the evaluation of the work is intended to obtain compensation that is close to worth and equity. Compensation is something employees receive in lieu of their service contributions to the company. Compensation is one of the implementation of MSDM function related to all types of individual awarding in exchange for carrying out organizational duties.

Compensation or reciproge is generally intended for the benefit of the company and its employees. The interests of a company with compensation are obtaining greater employment achievement rewards from employees. While the interest of employees for compensation received is able to meet the needs and desires and become the economic security of the household. So it can be concluded that compensation is everything received by employees, whether money, goods or so on in return for their work in the organization. Compensation is also the main reason why most people work for the company, because with that compensation the employees can meet and improve their life needs. Given the importance of labor factors in an organization, organizations need to pay special attention to their employees to be more passionate in carrying out their duties in the company, because by providing decent and fair compensation will further spur their work motivation.

\subsection{Employee Performance}

Performance has a diverse understanding of various experts, but still has similarities in general. Performance is the level of achievement or the results or an implementation of particular task. The company's performance is the level of achievement of results in order to realize its goal. Moreover, the information about organizational performance is very important to evaluate whether the performance process carried out by the organization so far is in line with the expected goals or not. But, in reality many organizations are precisely lacking or even rarely anyone has information about performance in their organization. Performance as a result of the functions of the work / activities of a person or group in an organization influenced by various factors to achieve the objectives of the organization in a certain period of time. Performance is the result of work that can be achieved by a person or group of people in an organization in accordance with their respective authorities and responsibilities in an effort to achieve the objectives of the organization.

Performance is the willingness of a person or group of people to do something and refine it according to its responsibilities with results as expected61.Performance or achievement of work is a work achieved by a person in carrying out the tasks charged to him based on skill, experience, and seriousness as well. Performance in general is the face and image of employees reflected from an organization, but in proper application is not easy, because human nature consists of various characteristics and has different feelings, dispositions and abilities understanding.

Based on the performance understanding above, the opinions it can be concluded that performance is a result of the work achieved by a person in carrying out the tasks charged to him and how much they can contribute to the organization.Performance also means the results achieved by a person, both quantity and quality in an organization in accordance with the responsibilities given to them.

Performance Assessment is known as performance rating, performance appraisal, personnel assessment, employ evaluation, merit rating, efficiency rating and service rating. 
Performance assessment is a process where a supervisor evaluates/assesses and reports on performance, achievement level, willingness and potential for further development. There are several definitions of performance evaluation from experts, namely:

1. Performance assessment is a system of periodic review and evaluation of the performance of an employee, usually an assessment done by the supervisor.

2. Performance assessment is a procedure that assists in the collection, cheking, sharing, providing and utilizing the information collected from the workers themselves in their work with the aim of improving their performance.

3. Performance assessment is a process carried out by the company in evaluating the performance of a person's work, if this is done correctly, then the employees, supervisors, HR departments, and finally the organization will benefit with the strategic focus of the company.

There are three steps in assessing achievement: First is to define a job that means that subordinates and superiors agree on employee work standards. Second, assess achievements that mean comparing employees' achievements to established standards. Third, feedback is to discuss the performance that subordinates have done and make plans for a necessary development. The purpose of performance evaluation is to ensure the achievement of the goals or objectives of the organization. However, performance evaluation can show the position and level of achievement or objectives of the organization so that it can be accelerated in case of delays and improvements in case of irregularities. The objectives or objectives of work evaluation are grouped into three parts, namely:

a. Administrative, administrative objectives of performance evaluation is intended to be the result of performance evaluation can be used as the best material to develop organizational policies, for instance in providing the best and regular materials as the basis for determining promotions, mutations, or raises / wages.

b. Informative, the results of performance evaluation will be a sufficient source of data for management, especially about the performance of employees or subordinates. And for employees themselves performance evaluation is a source of data about their respective strength and weaknesses.

c. Motivation to create a learning experience that can motivate employees to always develop themselves and improve their performance.

Performance evaluation is intended to determine the achievement of organizational goals, achievement of work unit goals, achievement of group goals and individual goals. Performance is one measure of actual behavior in a multidimensional workplace, where performance indicators include work quality, quantity of work, working time and cooperation with colleagues.

1. Quality of Work

Both companies are engaged in manufacturing and services. Also the provision of quality products is a demand for organizations to survive in various forms of competition. Increasing purchasing power and consumer support to the existence of quality of work offered, will further improve the sustainability of the organization in achieving the goals set.

2. Quantity of Work

Market mastery is one of the marketing strategies that must be the main consideration for the company. Therefore, the quantity of production will determine the ability of the organization to master the market by offering as many products as possible that are capable of being produced. Through the quantity of work that can be produced the 
company is expected to give a positive impression on the position of products in the market.

3. Time Work

The company's ability to set the most efficient and effective uptime at all levels in management. Working time is the basis for an employee in completing a product or service for which he/she is responsible.

4. Cooperation

Cooperation is a long-term bond for all components of the company in conducting various business activities. Cooperation is a demand for the success of the company in achieving the goals set, because with good cooperation will give trust to various interested parties, either directly or indirectly with the company. To realize good cooperation, the company must be able to build a constructive internal condition of the company followed by a high commitment and consistency for all management principles.

Performance assessment must be directly related to the analysis of the work that determined the performance output includes: the tasks carried out, individual competencies, supervisory activities and budgeting responsibilities for officeholders. Therefore, the performance is considered as a function, ability and willingness. There are several measurements of employee performance, among others, using aspects of loyalty, work achievement, honesty, discipline, creativity, initiative, leadership cooperation, personality, proficiency, and responsibility. Those things above are called performance assessment system. A company certainly and demands that all its employees in all ranks of the company perform their best. To find out if it happens in a company created a performance assessment system both aimed at employees who occupy managerial positions and those whose main responsibility is to conduct various operational activities. The most commonly implemented system is what is known as the Job Implementation Assessment List. The elements of working implementation that assessed in the Assessment List of Work Implementation namely: Loyalty, Work Achievement, Responsibility, Obedience, Honesty, Cooperation, Initiatives, and Leadership. Some of things above are opinion in the measurement of performance. In this study used the elements of performance assessed called Work Achievement, Responsibility, Obedience, Honesty, Cooperation, Initiatives.

a. Elements of Work Achievement. Work Achievement is the result of the implementation of work achieved by an employee in carrying out the duties charged to the employee. An employee's work performance is influenced by their skills, skills, experience, and seriousness and work environment.

b. Element of Responsibility, is the ability of an employee in completing the work submitted to him or her as best as possible, on time and dare to take risks for the decisions taken or actions taken.

c. The element of obedience, is the ability of an employee to obey all applicable rules of service, and obey the orders of the ministry given by the authorized superiors, and able not to violate the prescribed prohibitions.

d. The Element of Honesty honesty is a mental attitude that comes out of the human being. That is sincerity in carrying out his duties and is able not to abuse the authority and responsibility given to him.

e. The Element of Cooperation, is the mental ability of an employee to be able in working together with the others in completing predetermined tasks.

f. Prakarsa or Initiative, is a translation of the initiative. It is an employee's ability to make decisions, steps, and implement in accordance with the actions required based on the implementation of basic tasks without waiting for the orders. 
Performance assessment is carried out to assess employee performance by using performance assessment form with the following predetermined assessment categories such as: Teamwork; Willingness to accept changes; Carrying out superior orders in a positive sense; Providing useful inputs for service improvement; Working hours and work schedules are always fulfilled; Rest in accordance with the schedule that has been determined; Never get an oral or written reprimand; Wear a uniform in accordance with the schedule that has been set by the policy maker.

\section{Research Method}

This research employs quantitative approach method. The source of research data in the form of primary data obtained directly from the questionnaire filled directly by respondents. Data collection method here has used the questionnaires that have previously been tested for validity and reliability. The population in this study was all employees in DAPM Bina Mandiri as many as 104 people taken with simple random sampling techniques of $75 \%$ then obtained a sample of 74 people. Data analysis techniques use multiple linear regression analysis. Multiple Linear Regression is used to determine how much influence variables are free from this research, namely: Work Motivation, Competence, and Compensation to the bound variables that are Employee Performance.The common equations of multiple linear regression are as follows:

$$
\begin{array}{ll}
\mathrm{Y}=\mathrm{a}+\mathrm{b} 1 \mathrm{X} 1+\mathrm{b} 2 \mathrm{X} 2+\mathrm{b} 3 \mathrm{X} 3+\mathrm{e} \\
\mathrm{Y} & =\text { Employee Performance } \\
\mathrm{X} 1 & =\text { Competency Variable } \\
\mathrm{X} 2 & =\text { Work Motivation Variable } \\
\mathrm{X} 3 & =\text { Compensation Variable } \\
\mathrm{a} & =\text { Constanta } \\
\mathrm{b} 1, \mathrm{~b} 2, \mathrm{~b} 3 & =\text { Coefficient Regression Line } \\
\mathrm{e} & =\text { Error }
\end{array}
$$

\section{Results and Discussions}

\subsection{The Objective of Research}

The population as well as the samples used in this study were all managers of DAPM Bina Mandiri Boja Subdistrict, totaling 37 people. Thus, all dapm bina mandiri managers are respondents in this research. The questionnaire distributed was intended for all dapm managers of Bina Mandir amounted to 74 , and the total questionnaire was returned as many as 74 bundles.

\subsection{The Characteristic of Respondent}

Table 1. The Distribution of Respondent Characteristic $(\mathrm{n}=74)$

\begin{tabular}{ccc}
\hline Characteristic & Total & Percentage (\%) \\
\hline & Gender \\
\hline
\end{tabular}




\begin{tabular}{ccc}
\hline Characteristic & Total & Percentage (\%) \\
\hline Female & 48 & 35,14 \\
Male & 26 & 64,86 \\
\hline \multicolumn{3}{c}{ Time of Work } \\
\hline$<2$ years & 2 & 2,70 \\
2-5 years & 10 & 13,51 \\
6-8 years & 40 & 54,05 \\
$>9$ years & 22 & 29,73 \\
\hline \multicolumn{3}{c}{ Education } \\
\hline Senior High School & 54 & 72,97 \\
Diploma & 0 & - \\
Under Graduate & 18 & 24,32 \\
Graduate & 2 & 2,70 \\
\hline
\end{tabular}

\subsection{The Result of Classic Assumption}

\section{a) Normality Testing}

Table 2. The Result of Normality Testing

\begin{tabular}{ccc}
\hline Variable & Probability & Result \\
\hline Unstandardized Residual & 0,339 & Normal \\
\hline Source: The processing data in 2019
\end{tabular}

Based on the results of normality testing above through residual values obtained the value of 0.339 .This probability number is greater than 0.1 this explains that the residual data of the estimated result indicates a normal spread of data.Thus the data in this research is in accordance with the regression equation.

\section{b) Multicollinearity Testing}

Tabel 3. The result of Multicollinearity Testing

\begin{tabular}{lccc}
\hline \multirow{2}{*}{ Variable } & \multicolumn{2}{c}{ Collinearity Statistics } & \multirow{2}{*}{ Simpulan } \\
\cline { 2 - 3 } & Tolerance & VIF & \\
Work Motivation (X1) & 0,526 & 1,900 & Free of Multicolliniearity \\
Competency (X2) & 0,510 & 1,959 & Free of Multicolliniearity \\
Compensation (X3) & 0,559 & 1,790 & Free of Multicolliniearity \\
\hline \multicolumn{4}{c}{ Source: The processing data in 2019 }
\end{tabular}

From table 3 above, it is known that the VIF result of each variable is below the value of 10 and has a tolerance value above 0.10 . This assessment indicates that all variables used are free of multi-covaririty problems or there is no correlation between free variables.

\section{c) Heteroscedastic Testing}

Table 4. The Result of Heteroscedastic Testing

\begin{tabular}{lccc}
\hline \multicolumn{1}{c}{ Variable } & number & SIG & Result \\
\hline Work Motivation (X1) & 3,623 & 0,001 & Free of Heteroscedastic \\
Competency (X2) & 1,717 & 0,095 & Free of Heteroscedastic \\
Compensation (X3) & 2,905 & 0,007 & Free of Heteroscedastic \\
\hline
\end{tabular}

Source: The processing data in 2019 


\section{d) Hypotheses Testing}

Hypothesis testing consists of $\mathrm{t}, \mathrm{F}$ and determination coefficients $\left(\mathrm{R}^{2}\right)$

\begin{tabular}{lcc}
\multicolumn{3}{c}{ Table 5. The Result of Double Regression Linear. } \\
\hline Independent Variable & B & Standard Error \\
\hline (Constant) & 3,104 & 1,344 \\
Work Motivation & $-0,135$ & 0,071 \\
Competency & 0,088 & 0,056 \\
Compensation & $-0,033$ & 0,065 \\
\hline
\end{tabular}

Source: The processing data in 2019

From table 5 can be arranged regression equations as follows: $\mathrm{Y}=3.104-0.135 \mathrm{X} 1+0.088 \mathrm{X} 2-$ $0.033 \times 3$

\section{e) Model Feasibility Testing (Testing F)}

Table 6. The result of F-testing

\begin{tabular}{cccc}
\hline Dependent Variable & F counting & P value & Result \\
\hline Employees Performance (Y) & 31,844 & 0,000 & Signifikan \\
\hline \multicolumn{4}{c}{ Source: The processing data in 2019}
\end{tabular}

In the table 6 above, it can be seen that the value of Fhitung is 31.844 with a probability of 0.000 (pvalue $<0,1$ ). This means that discipline, training and work motivation have a significant positive effect on employee performance, so that the first hypothesis (H1) is accepted.It also shows that the regression model used is fit or healthy (goodness of fit), so this research model is worth using.

\section{f) T-Testing}

Table 7. The result of T-Testing

\begin{tabular}{cccc}
\hline Variable & T - Counting & P value & Result \\
\hline Work Motivation & 1,902 & 0,046 & Approved \\
Competency & 1,566 & 0,027 & Approved \\
Compensation & $-0,501$ & 0,620 & Declined \\
\hline
\end{tabular}

Source: The processing data in 2019

\subsection{Discussion}

\section{a) The Effect of Work Motivation on Employee Performance}

Work motivation has a significant positive effect on employee performance, so the first hypothesis is accepted. From the t-testing analysis it is known that work motivation variables have the most dominant influence on employee performance compared to the other two independent variables. The underlying motivation of a person to carry out work is a very important factor and most affects the performance of employees. Therefore, the role of agency leaders must be more active in order to encourage employees as a form of motivation in achieving agency goals. Things that can be done by the agency in order to improve the performance of its employees, among others, by awarding awards for outstanding employees 
by providing scholarships to continue higher education or can be in the form of compensation such as gifts that can trigger their work creativity. The results of this study reinforce to the results of previous research conducted by Munir et al (2017); Ranu and Sutopo (2016); Rachmawati (2016) provides empirical evidence that work motivation has a significant effect on employee performance.

\section{b) The Effect of Competence on Employee Performance}

Training has a significant positive effect on employee performance. Well, second hypothesis is accepted. This means that the more often employees attend training, the more supportive the employee performance will be, and vice versa. Therefore, the leadership and agency officials must increasingly provide the widest number of opportunities for employees to participate in various kinds of training in accordance with their respective auth in the office. The more training, the more employee performance development will be increased. The results of this study strengthen to the results of previous research conducted by Sefriady and Iskandar (2018); Widodo et al (2018); Hayati and Haryani (2016) provide empirical evidence that training has a significant impact on employee performance.

\section{c) The Effect of Compensation on Employee Performance}

Compensation has no effect on employee performance, so the third hypothesis is rejected. Based on the test results above, it can be interpreted that there is no influence between compensation variables on employee performance at DAPM Bina Mandiri Boja. This is happened because there is another motivation from DAPM Bina Mandiri Boja employees. In addition, those things are having a high sense of solidarity to be with DAPM Bina Mandiri Boja can educate the nation's children as a form of service to the community who need it.

\section{Conclusion and Suggestion}

\subsection{Conclusion}

The results showed that work motivation and competence have a significant positive effect on employee performance. While compensation has no effect on employee performance. Well, it can be interpreted that with the motivation of work and competence, it will be able to improve employee performance. 1

\subsection{Suggestion}

Based on the conclusion above, the suggestions can be given as follows:

a. It is necessary to continuously increase the capacity of DAPM Bina Mandiri Rural employees.

b. In addition, it is also necessary to pay attention again about the income of employees who have been received, namely by providing additional honors or wages for employees who excel or do work other than the burden of duty.

c. It is necessary to review and make improvements to the amount of compensation that given to the employees in accordance with their respective levels of education. 


\subsection{The Limitation of Research}

a. There are still some questionnaire answers that have not been consistent according to the observations of researchers. Respondents did not fully observe the questions asked. This can be anticipated by accompanying and supervising respondents in filling out questionnaires.

b. Organizational conditions are not ideal with the presence of a part-time workforce.The number of part-time workers is more than the permanent workforce in DAPM Bina Mandiri.

c. Organization is a continuity of the empowerment program of the government. Thus relates to the existing culture of that based on the empowerment, not a business institutions.

\subsection{For the Next Research}

a. The other research can provide improvement by adding variable indicators used in research questions. This strategies are better with the basis of the theory that is in accordance with organizational conditions.

b. Sorting of employee status is necessary in order for future research to reflect the condition of the results as a reality.

\section{References}

[1] Ariyanti, N., 2014. Pengaruh Budaya Organisasi Terhadap Kinerja Pegawai. Jurnal Manajemen \& Bisnis, 14(2), pp. 144-150.

[2] Dessler, Gary, 2006. Manajemen Sumber Daya Manusia. Edisi ke sepuluh. PT Intan sejati. Klaten.

[3] Echols, J. dan Shadily, Hasan, 1996. Kamus Bahasa Inggris Indonesia. PT Gramedia, Jakarta.

[4] García, M. Ú., 2005. Training and business performance: the Spanish case. The International Journal of Human Resource, pp. 1691-1710

[5] Ghozali, Imam, 2005. Aplikasi Analisis Multivariate dengan program SPSS.

[6] Gordon, Anderson, 1992. Managing Performance Appraisal System. Uk. Strathclyde Bisnis School

[7] Gibson, Ivancevich, dan Donnely, 2004. Organisasi. PT Erlangga, Jakarta.

[8] Hasibuan, Malayu, 2007. Organisasi dan Motivasi. PT. Bumi Aksara, Jakarta

[9] Husein, Umar, 2002. Metode Riset Bisnis. PT. Gramedia Pustaka Utama, Jakarta

[10] Ivancevich, J. M. Konopaske R. dan Matteson M.T., 2005. Organizational Behavior and Management. Seventh Edition. The McGraw-Hill Companies. Edisi Bahasa Indonesia, Gina Gania, 2006. Perilaku dan Manajemen Organisasi. Erlangga, Jakarta.

[11] Kennaa, E. and Beach, N., 2002. The essense of Human Resource Management. Penerbit Budi, Yogyakarta.

[12] Mangkuprawira, Sjafri, 2009. Bisnis, manajemen, dan Sumberdaya Manusia. PT. Gramedia, Jakarta.

[13] Malthias, R. L. Dan Jakson, 2006. Human Resource Management. Australia - South Western.

[14] Malthias, R. L. dan Jakson, 2002. Manajemen Sumber Daya Manusia. Jakarta. 
[15] Manulang, M., 1994. Manajemen Personalia. Ghalia Indonesia. Jakarta.

[16] Notoatmodjo, Soekidjo, 2009. Pengembangan Sumber Daya Manusia. PT Rineka Cipta, Jakarta

[17] Rampesad, Hubert, K., 2006. Pertajam Kompetensi Anda dengan Personal Balance Scorecard. Sinergikan Ambisi Pribadi dengan Ambisi Perusahaan Anda. Edisi Indonesia. PPM, Jakarta.

[18] Robbins, S. P., dan Judge, Timothy A., 2008. Perilaku Organisasi Edisi keduabelas Salemba Empat, Jakarta.

[19] Ruky, Achmad, 2006. Sumber Daya Manusia Berkualitas mengubah Visi menjadi Realitas. PT. Gramedia Pustaka Utama, Jakarta.

[20] Schuler, R. S. J.,1999. Strategic Human Resource Management. Mass. Blackwell Publishers, USA.

[21] Siagian, S. P., 2004. Manajemen Internasional. PT Bumi Aksara, Jakarta.

[22] Simanjuntak, P., 2005. Manajemen dan Evaluasi Kinerja. Lembaga penerbit FE UI, Jakarta

[23] Stoner. J. A. F dan Edward Freeman R., 2003. Manajemen. PT Prenhallindo, Jakarta.

[24] Soeharyo, S. dan Sopiah, 2008. Perilaku Organisasional. Penerbit Andi Yogyakarta

[25] Sung, S. Y. \& Choi, J. N., 2016. To invest or not to invest: strategic decision making toward investing in training and development in Korean manufacturing firms. The International Journal of Human Resource Management, 18(5), pp. 2080-2105

[26] Supranto, J., 2001. Statistik: Teori Dan Aplikasi. Edisi keenam. Erlangga, Jakarta

[27] Tika, P., 2006. Budaya Organisasi Dan Peningkatan Kinerja Perusahaan. PT Bumi Aksara, Jakarta

[28] Veithzal, Rivai, 2008. Performance Appraisal: Sistem Yang Tepat Untuk Menilai Kinerja Karyawan Dan Menigkatkan Daya Saing Perusahaan. PT Raja Grafindo Persada, Jakarta.

[29] Veithzal, Rivai, dan Ella, Jauvani, 2009. Manajemen Sumber Daya manusia untuk Perusahaan. PT Raja Grafindo Persada, Jakarta.

[30] Wahyudi, F., 2014. Peran Kompetensi Dalam Meningkatkan Kinerja Pegawai. Jurnal Paradigma, 3(2), pp. 186-197.

[31] Wibowo, 2008. Manajemen Kinerja. PT grafindo Persada. Jakarta.

[32] Yukl, Gary, 2006. Leadership in Organizations. Edisi ketujuh, Universitas at Albany State University of New York

[33] Youndt, M. A., Snell, S. A., Dean, J. W. \& Lepak, D. P., 1996. Human Resource Management, Manufacturing Strategy, And Firm Performance. Academy of Management Journal, pp. 836-866.

[34] Zhang, Q., Vonderembse, M. A. \& Jeen-Su, 2010. Value chain flexibility: A dichotomy of competence and capability. International Journal of Production Research, 40(3), pp. 561-583.

[35] Zigarmi, D. \& Peyton, T., 2018. Work Locus of Control, Motivational Regulation, Employee Work Passion, and Work Intentions: An Empirical Investigation of an Appraisal Model. Journal of hapiness study, 44(19), p. 231-256. 